AL-TA'LIM JOURNAL, 24 (2), 2017, (142-156)

(Print ISSN 1410-7546 Online ISSN 2355-7893)

AI. DTAIIIN

लिएकसल

Available online at http://journal.tarbiyahiainib.ac.id/index.php/attalim

\title{
The Contribution of Zapin as One of Malay Traditional Arts in Curriculum 2013
}

Received:02 ${ }^{\text {nd }}$ March 2017; Revised: $18^{\text {th }}$ Mei 2017; Accepted: $25^{\text {th }}$ July 2017

Permalink/DOI: http://dx.doi.org/10.15548/jt.v24i2.270

\section{Ellya Roza*)}

Universitas Islam Negeri Sultan Syarif

Kasim Riau, Indonesia.

E-mail: ellya_roza@yahoo.co.id

\section{Nur Aisyah Zulkifli}

Universitas Islam Negeri Sultan Syarif

Kasim Riau, Indonesia.

E-mail: n.aisyahzulkifli@yahoo.co.id

*) Corresponding Author

\begin{abstract}
Zapin consists of three elements which are complementary to create movement harmony and rhythm that beautiful to look, heard and seen. They are music, song and dance. Zapin is one culture comes from Arab that developed in archipelago line with Islamization process. Zapin in Nusantara grew and developed in accordance with the customs and conditions of the local community. It becomes palace art for events such as welcoming guests and celebrations in the kingdom and also entertainment for society. The study aims to determine the contribution of Zapin in the Curricullum 2013. A Mixed research was used where the data taken from documentation, observation, and interview. The finding of the study showed that although modern art has been rife enter and expand in the archipelago but Zapin as cultural heritage still exist in society because of its content in accordance with teaching point and attitude of society that moral and spiritual precedence. It means that Zapin with all devices containing a core competence value contained in curriculum 2013. It is concluded that the contribution of Zapin as one of Malay traditional arts might contribute to the strengthening of curriculum 2013.
\end{abstract}

Keywords: Contributions, Zapin, traditional arts, core competencies, curriculum 2013.

How to Cite: Roza, E., \& Zulkifli, N. (2017). The contribution of Zapin as one of Malay traditional arts in curriculum 2013. Al-Ta Lim Journal, 24 (2). doi:http://dx.doi.org/10.15548/jt.v24i2.270

\section{INTRODUCTION}

Moral and spiritual crisis is the main issue faced by mankind today where humans are far from good scolds courtesies, teaching, respect and so especially with regard to the ethics of life. There are only chided, blamed reproach, recriminations, open disgrace people and many others. This moral crisis resulted in very many disasters, whether natural or human disasters on itself. In terms of science is very advanced and high technology. Is science no longer has a significant correlation with human morality? In case, Al-Qur'an clearly says that those who have knowledge received an award from Allah Swt raising dignity and status.

Science is not only acquired through formal education but can also be obtained through non-formal education such as associations, non-governmental organizations, social organizations, arts associations and other 
associations. Non-formal education will be very urgent to human benefit because the process is not binding but has a great sense of responsibility towards the procession. Its members have special interests when entering the realm of non-formal education because it will be dealing directly with various models of its members. Therefore, it is needed attitude and manners while in environment so that the benefit achieved. This competence contained in curriculum 13 as an effort to realize the benefit.

The core competencies that will be discussed in this paper are contained in Zapin traditional arts which Zapin grow and develop in Nusantara tandem with the process of Islamization by Arab. Zapin as Arab art had come to proceed, causing the interaction between migrants and host communities are ultimately local communities experiencing social institutions new life. Assimilation and adaptation between Arab and society are created through various touches Zapin as a form of art. It cannot be denied the existence of Zapin in Nusantara regarded as a learning which can be appreciated in attitude among society in order to establish a relationship and factual communication.

Zapin gives color in society life, value and contribute to the education world; both general and special education such uphold customs, enforcing discipline and show religious attitude and good character. Zapin as a legacy of Arab considered very alluring be milestone relationship as well as entertainment relieving tired. It meanst through Zapin community gathering, happiness, and preaches so that its existence is very appropriate as a means of connecting a sense that contains a variety of messages, mandate and role models. Meaningful when gathered in doing zapin, people greet, advise and teach each other Aqattitude in accordance with the guidance of religion. This is very consistent with the curriculum 2013 (then abbreviation K.13) core competencies of K.13 contain spiritual values as found in the arts Zapin. Therefore, these papers want to measure to extent the contribution of Zapin Malay as a traditional art toward K.13 which is being developed by the government today.

\section{METHOD}

A mixed research was used in this study where the data taken from documentation, observation, and interview. In other words, both qualitative and quantitative approaches were conducted (Bernard, 2011; Bryman, 2006; Creswell, 2013; Creswell \& Clark, 2007; Elo \& Kyngäs, 2008; Hsieh \& Shannon, 2005; Neuman, 2002; Thomas, 2006). This combination is done with expectation to enrich the data and better understand the problems studied. It means that this article would result in a new understanding by using content analysis. Furthermore, the presentation presented descriptively giving something description and a detailed description or depict the complex reality that explanation and interpretive analytical achieved. Thus the way of writing used by the chronology of the events applies to entire period and scope of the study. This can help to simplify and explain about something that dealt with the issue in order to make the conclusions more critical.

\section{RESULT AND DISCUSSION}

To understand the meaning and word of Zapin, it derived from Arabic AlZapn. In Zihabi Dictionary, the word of Al-zapn means dancing or same as Raqsun which means act or swapping. While in Arab-Indonesian Dictionary the word of Al-Zapn ordof derived from the wzafana-yazfinu-zafnan which means "dance", "kick". While the word of raqsun derived from the word raqasayarqusu-raqsan which means "dance," "dance" and "bertandak". The word of Zapin derived from Al-zapn which means "dance" and corresponds with Raqsun meant "act" or "swapping". Al-zapn derives from word of zafana-yazfinu-zafnan which meant "dance" or "kick ". Raqsun derived from the word of raqasa-yarqusu-raqsan which means dancing (Berg, 2007; Burridge, n.d.; Chong, Rohwer, 
Emmanuel, Kruse, \& Smilde, 2013; Houston, Stuart, \& Taube, 2013; Meddegoda, 2013; Ritawati, 2017; Shuaib, Olalere, \& others, 2013).

Refers to the origin word of Zapin above, it can be said that Zapin is one of art uses leg movement as the base tempo and dynamics. Leg movements arise because of the gust of glad and pleasure will be accompaniment of musical instruments drums and other instruments played by musicians to produce leg and body movements such as hands and head. Zapin is developed rapidly from one to another region coincide Arabs trading processes to various parts of archipelago, including Indonesia. Archipelago was once a Malay region which is a trade channel of foreign nations for main purpose because spices produced is very attractive to the merchant. It meant Zapin is art of living and thrive in Malay formerly known as Archipelago and influent in society life.

Zapin is one proof of community local knowledge in art. Zapin has attached with custom and appreciated legacy all the time. There are many values can be taken and picked from Zapin as a legacy such as in the case of dance, music and song. Therefore, Zapin is called differently, such as in West Kalimantan name Jepin, in Banjarmasin and South Kalimantan name Panting, in Makassar and South Sulawesi name Jepeng, Banten and West Java name Japin, in Jambi name is Dana and in Riau name Zapin. So it also in Land of Peninsular Malaysia, Thailand and Singapore is known as Zapin. Different designations indicating Zapin is an art developed in archipelago society formerly known as Malays.

Zapin essentially consists of several elements namely dance, songs and music. Music is as Zapin dance accompanist useful for the beauty of motion and tempo step in delivering meaningful speech. Music consists of several musical instruments such as harps, and Marwas where mutually supporting chock creates strains of tones and rhythms lovely causing strains harps lilting (Ross, 2011).

Since long ago, Zapin musical instruments at Nusantara are used psaltery and Marwas even though at first in Arab the instruments used Al-udand Tambour (Alfirafindra, 2012; Astuti, 2016; Nor, 2000b, 2000a). It has been agreed that to communicate with people around the empire is done through a particular sound produced by a device, for example cymbals and so forth. Likewise, Zapin is the instrument used as a tool or means of communication that occurs between the players and society as a listener (Ibid). On subsequent development, the sound that has been known and used by society are then arranged into a tone be regularly sounds and has rhythm sounds in accordance with the situation and conditions. According to Arzull (2002); Junita (2015); Nurdin (2016), in Zapin music, the most important thing is the melody while Marwas unison add distinctiveness of the music so that the punch with another blow and shouted to produce harmonious sounds.

\section{History Origins Zapin}

It is estimated Zapin created in the sixth year of prophet that when Prophet Muhammad Saw asked Ja'far as caretakers SaidinaHamzah daughter who want to join the Prophet Saw migrated to Medina. Ja'far was immediately delighted and danced and lifted his feet and swung his legs repeatedly as a sign of excite over the decision of the Prophet. Based Ja'far leg movement, which was also attended by Ali, then from here started their spontaneous movements by leg movement developed in the Arab society as a sign of love and excite at an event experienced. Leg movements then became a habit to do if there were events that eventually became an entertainment for society at that time and known the word al-zafn that connotes be Zapin. This happens when start to appear truce with infidels of Mecca (Hilarian, 2005). 
As stated at the beginning of the discussion before, the existence of Zapin is not separated from the process of Islamization in archipelago. Zapin entered into various areas and regions together with the traders and Islam spreader. Therefore Zapin become one of the thriving local arts communities in Indonesia. One country entered by Zapin is Siak. Siak is the capital of the Siak Kingdom which receive Zapin when the kingdom led by sultan Arab descent that began in seventh sultan namely Sultan Said Syarif Ali (1764-1780), grandson of Sultan Alamuddin Syah had son-inlaw Arab descent. Sultan Alamuddin daughter named Tengku Kamariyah marry Said Syarif Osman Arab descent from Ba'lawi tribes. From marriages born children Sultans Siak of Arab tribes so the last sultan namely Sultan Syarif Kasim Abdul Jalil Saifuddin, the influx of Arab tribes in the Kingdom Siak. Since Arab tribes come to Siak kingdom, it began Arab culture enter. Thus, Zapin became art palace, especially when holding the event, both religious and entertainment.

Zapin journey from its origin namely Arabic evolve rapidly so that one region and other are equally a touch of Arab art. Society archipelago with its open easily accepted art comes from outside. The process of Islamization was instrumental to the existence of Zapin at this archipelago. it was once a regional trade channel of foreign nations, even became the main destination for foreign because spices produced is very attractive to the merchant. Therefore, it can be said that the journey of Zapin from Arabic to archipelago none other for Islamization process undertaken by Arab traders. This means Zapin Arab developed at archipelago simultaneously with Islamization process to various parts in archipelago (Abdullah \& Pakri, 2013; Farrer, 2012; Kartomi, 2012). Research result of Nor (2000b) states that Arabs have done trade relations to archipelago long before archipelago Islamization process. Even further said that the earliest contacts between the two regions, especially with regard to trade has been started since the time Phunisia and Saba where boats
Arab and Persian trading to China do odyssey also in the archipelago. This happens because at that time the Malay Archipelago has been a haven trader who sailed to China and they have a relationship with the surrounding community, especially the coastal areas. Likewise Wolf (2010) have predicted that trade relations in the continent of Asia, in particular the relationship between Arabic, Persia, China and India have grown since the beginning of our era.

\section{Zapin as Malay Traditional Art}

Since Zapin Arab grew and developed in the archipelago, People in each region received Zapin as entertainment media so Zapin came from Arab developed in accordance with the conditions of supporters. Due to differences in nature and earth between Arab and archipelago, then there is a change to any device Zapin causes condition and situation in Arab was not same as the conditions and the situation of local community. Zapin origin was known Zapin Arab Emirates and in its development, exchanged names with the name Zapin Malay. Music equipments have also been changed, for example the string instrument $\mathrm{Al}$ Ud

with Lute, whereas Tambur replaced

exchanged by Marwas. Likewise, Zapin dance from Arabs had no interest or variety in dance movements. Zapin Arab dance did leg movement just jump and circular while Zapin Malay dance has a variety or interest dance. Then, the song is sung as a Zapin Arab dance progressing well because Malay nature varied consisting of sea, islands, hills, mountains and coast, the rhythm and characteristic are very different from its natural Arab Zapin that consists of Deserts. Therefore, ultimately in archipelago community Zapin Malay is known appellation with its trademark. According Chan \& Ching (2012); Firzal (2015) stated that form of Zapin Malay as a sign of local genius play a role in its time to cultivate a culture that comes into host communities so Zapin culture with all the devices very dominating and become a tradition of Malay society. 
By coming and development of Zapin in archipelago as a form of art that is based on Islam, then the form of community art closer to Islamic values and Zapin used as a barometer of daily life in relationship, considerate and sharefor, solace as well as a gathering place for the community. Traces and tread of Zapin in Malay signifies indicate cultural acculturation and life for Malay community has been approached by the Arabs. The presence of Arab nation for centuries gradually experiencing unity with local communities, including Zapin as a form of art that ultimately institutionalized and become integral part of life.

Since the introduction of Zapin Malay term by a bustling community, Zapin Melayu always dominates in Malay life community in averaging in Malay earth. Breath and pulse Zapin still flows like river flow and sea. Zapin unity with daily life community and spirit of Zapin enter into the hearts of everyone who inhabits Malay earth. It was swung by the presence of Zapin containing beauty characteristic because the unity between songs, music and dance are combined into one. Therefore Zapin Malay became an artistic community art that was originally formed by environment influenced, both ethnically and age. For example, the influence of art before Islam came were China and India, while the Arabs affect the arts in tandem with Islamization process at archipelago. Thus, the traditional Malay art has many kinds and variety. This is of course due to the role of local genius that exists at that time. They adopted from entrants who are at that time came to the Malay lands to conduct trade transactions so manifest traditional art with various tramp like dancing, Mak Inang, Zapin, Langgam and so forth. Langgam influenced by Chinese dancing and Mak Inang influenced by India while Zapin is the influenced by Arabs which later develops Rebana, Marhaban, Berzanji, Nasyid and others as an art express Islam.

If further review concerning the existence of backward countries today, such as
Indonesia, Malaysia, Singapore, Brunei Darussalam and other neighbouring countries can be said that during the early and late in $17^{\text {th }}$ until $20^{\text {th }}$ century decade known as Archipelago. From the point of geology, Anderson (2013) noted that this archipelago begun in the mid Pluvial era where the shape of the island was very different to the current situation. At Glacial times, the archipelago united with Southeast Asia and in the late Glacial times sea water up to form South China and Java Sea. At this time, Musi, Batang Hari, Kapuas and other rivers meet in between Sumatra and Borneo islands where both its drain water into South China Sea. Therefore, fish contained in these rivers have the same kind. And like wise. There are similarities to the animals and plants found in the forests of the country.

Archipelago is known as 'negeritropis' that a lot of rain fall which caused many woods. This case is different from American continent and Europe where in Pluvial became very hot dry times so that there were vast deserts. At that time, it estimated the spread of humans. The first phase is We do ide tribes that have characteristics and recognized by experts as the first tribe who in habit this archipelago. They were nomadic because their life only depend on nature. The rest of tribe was known as backward tribes or tribal (Glatzer, 2002).

There were transition for tribes, where the transition was from wandering life to farm and settle in New Stone Ageor Neolithicum. Then, Malay race came in two phases. The first is a clump of Proto-Malayrace, around 2500$1500 \mathrm{BC}$ is expected to come from Asia, spread to Malay Peninsula Land and archipelago west as Sumatra. They advocated a culture of the New Stone Ageor Neoliticum. This periode along with Metal era to the time of Batu Besar or Megaliticum. Furthermore, Glatzer (2002) stated after that it came also DeutroclumpMalay race around the year $300 \mathrm{BC}$. This tribe sent forcé Proto-Malays tribal in land and mixes with the new arrivals. From the 
development of ethnic-Malay Deotro and engaging human child birth is now in its development is not less than the outside influences, especially with their trade relations.

The unity of people bonded by tribes exists in region, either in kingdoms as well as in other such as marriage and kinship (Tamrin \& Nur, 2007). In the western region of archipelago such as Sumatra, Borneo and Peninsular Malaysia adhesive significant are dominated by Malay race and Islam so that Malay language is said to be lingua franca of its time applied to Arabic-Malay or Jawi script written language as a medium of expression. This is what causes the communication and information between kingdoms and Malay society is very open and the frequency is high enough.

Malay kingdoms extremely instrumental in spices trade, especially pepper and tin mining resulted in emerging rivalry with each other. This competition is used by VOC to pit among Malay kingdoms. Furthermore, Malacca strait and South China Sea also enlivened by presence of Makassar Bugis who were displaced from the area due to interference of VOC in region, which in turn powers Bugis is given its own color in Malay region thus enriching the history and culture of Malay people.

Thus it can be said that Malay is
archipelago inhabited by various tribes. Therefore, the archipelago is a pluralistic society and consists of ethnic diversity in the various clusters of islands so that understanding of nation's culture cannot be separated from deep understanding of the nation's culture which derives from Malay or archipelago. This means concept of Malay is no longer a new concept because it is already presence along with human Proto Malays. Malay nature can be defined as a geographic region that covers the whole of human population using Malay language throughout Southeast Asia, especially in archipelago that is now units geopolitical or Indonesia countries, Malaysia, the Philippines, southern Thailand, groups in Cambodia and Vietnam and Taiwan. This understanding must be grounded to the language because language factor is the only remains of the ancient history of eternal still are valid and true marker will existence Malay neighborhood groups.

Geographically, according to (Sulistiyono \& Rochwulaningsih, 2013) Malay originated from Malay Peninsular Malaysia continues to Sumatra, Java, Kalimantan, Sulawesi and the islands of Nusa Tenggara and Maluku islands, including Irian and continue to Luzon and Mindanao island. Meanwhile, Othman (2005) said the view of Malay states refer to two things: geography and language. In terms of geography, Malays are concerned with ethnic about all the tribal communities who inhabit region stretching from southern Siam until the entire Malaysia today. So to all Indonesian regions is now recognized as a firsttime Nusantara, part of southern Philippines, include Sulu and Brunei Darussalam. Later in the developments taking place through a long history, it can be said that the community or people who inhabit Strait of Malacca, East Coast of Sumatra, Peninsular Malaysia and the countries mentioned by scholars above shows with a cultural pattern that is very much influenced by their religion namely Islam.

According to Peckham (2001) Archipelago trans-historical nature bound by unity bounded by two continents and two oceans. He also area that unite both continents and the oceans. In this area since the beginning it grew culture exposed to the world appears clearly traits in common. But at the same time, because of natural factors, history and other factors, it is part of being a highly diverse and colorful. Resident of this area has three identities: (1) Muslim; (2) speaking Malay; (3) having similarities in customs and traditions.

In the case of customs and traditions that apply to people in Malay nature principally involved with artistic traditions will have similarities despite differences were also seen to be but the difference is due to the result 
of local genius intellectual in developing the arts. In the words of Malay said:

Any sign spelled Malay, Sincere heart to face the rear. (Apa tanda Melayu terbilang, Hati ikhlasmukabelakang).

What are the signs of true Malay, Ikhlasnya not split for, Relanyacan not be purchased. (Apa tanda Melayu sejati, Ikhlasnya tidak terbelah bagi, Relanya tidak dapat dibeli).

Any sign of Malay habitual, Ikhlas associate fellow beings Abstinence sacrifice to be remembered, Helping people no mengupat. (Apa tanda Melayu beradat, Ikhlas bergaul sesame umat, Berkorban pantang diingat-ingat, Menolong orang tiada mengupat).

\section{Value Contain In Zapin}

Zapin give color in society life and even add value and contribute to educational world, both general education and special education are. This looks at all aspects of Zapin like music, songs and dances that contain life ethics such uphold customs, enforce identity and strengthen the unity and integrity.

Zapin as one of Arab nation's heritage and has become part of community art was regarded highly in accordance with shade of community archipelago because it can be used milestone relationship as well as entertainment relieving tired. With Zapin community gathering, happiness and preach so that its existence is very appropriate as a means of connecting a sense that it contains various messages and trustful. This means when assembled in order perform zapin, people greet each other, mutual respect, and edify each other. Therefore perform zapin activity can be described as one means of moral education and spiritual education for community. This is very consistent with core competencies contained in $\mathrm{K} .13$ as ongoing today.

This fact is not a manifestation today but artists Islam has contributed greatly to the development of art and civilization in the world. It is not only recognized by Muslim scholars but also recognized by Western scientists. Nor (2000a) view stated western duly indebted to Islam in incarnating various aspects of science and high proficiency in the arts and other areas in Europe. The glories of medieval and renaissance in Europe helped donated by Islam artists. Including Zapin brought by Arab artists to various areas layover in trading and Islamization. Then, Zapin ultimately transformed by Malay local genius thus becoming one of the traditional Malay culture.

Malay identical with Islam is a common statement heard by people in this world. Thus Zapin as an art is implementation of statement because it contains a teaching point pertaining to the moral and spiritual community. That is Zapin with all devices containing a core competence value K.13 though Zapin grew and developed in the various regions of archipelago, but the content value is not different.

To recognize the value should use five senses. However, the value obtained is still in abstract and used language symbols such good, moderate, very good, bad, and very bad. Therefore, as stated by Freud (2015) that the value is indispensable in society life so that direction of human civilization to be better, because value is usually oriented to truth, goodness, beauty, and unity. The other says that value is something potential, in the sense of relationship harmonious and creative so as to enhance human functioning.

Zapin as one of Arab cultural heritage that has been transformed by a local genius in the past and has now become one of traditional arts really loaded with value. Therefore it should be preserved as preserve national culture is one thing that is important in the search for 
identity and responsibility sense of each citizen. Art Zapin include voice or vocal song called Zapin, musical called Zapin music and dance known as Zapin dance. All of the three elements complement each other so that if people called Zapin, it would appear three elements because it is filling. It is meant according to Ross (2011) music is as Zapin dance accompanist useful for beauty of motion and tempo step in delivering meaningful speech. The music consists of several musical instruments such as psaltery/Gambus, and Marwas mutually supporting chock creates strains of tones and rhythms lovely causing strains harps lilting.

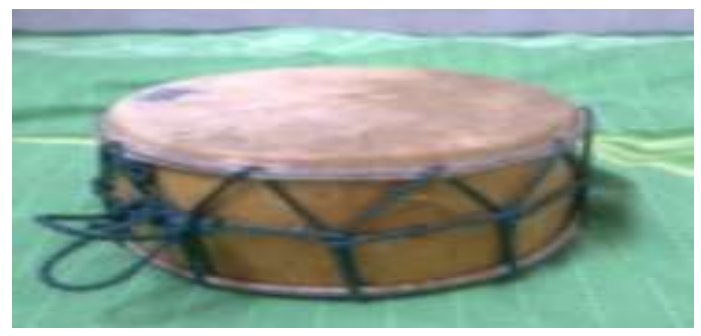

Figure 1. Gendang Zapin or Marwas

If one play and beat gendang Zapin named Marwas then produce from mouth 'tungtaktung'. This typical symbol gives a privilege for Zapin as an art spirit. Both of these instruments in accordance with shouted to each dance movement that step and jump like people are swapping. Tickling Lute and Marwas give typical value and the interrelationships between each component so that Zapin be respected and scintillating as an art that express education and laden with moral values, ethics and aesthetics because nice to heard and unsightly so as to provide the balance of breathtaking garden everyone who witnessed it.

\section{Curriculum 2013 (K.13)}

Curriculum 2013 began in 2013 and was held simultaneously in all parts of Indonesia which was held on the basics of affective for cognitive affective ability. Understanding of curriculum can be traced from the concepts of curriculum offered by the experts. Curriculum 2013 is a refinement of previous curriculum developed on the basis of educational theory based on the standards and competency- based. While K.13 is emphasizes on spiritual and social aspect. It is stated in the Ministerial Decree of Education about the basic framework and structure of the secondary school curriculum that establishes four core competencies (KI). Core Competence 1 deals with the attitudes and spiritual. Core Competence 2 is relating to social attitudes. In Senior school curriculum on core competencies 1 is formulated live and practice their religion. Core Competence 2 is to live and practice the honest behavior, discipline, responsibility, caring (mutual cooperation, cooperation, tolerance, peace), polite, responsive and pro-active as well as showing an attitude as part of the solution and various problems to integrate effectively with the social environment and the natural and put themselves as a reflection of nation in association world.

K.13 basically answers the demands UU.RI no.20 of 2003. Therefore, K.13 has a mission and burden of responsibility for growth and development of learners, give life meaning of goodness and virtue own life, community, state and nation even religion. That is, K.13 on core competencies is more emphasis on attitude and social aspects.K.13 applies not only formal education but also non-formal education, especially arts groups like a traditional art developed in the community. Traditional arts are meant art without using ICT in the process of implementation.

\section{Core Competence in Music and Song of Zapin}

Gambus has specialty as a minor-pitched musical instrument made of leban wood whose belly was covered with goat skin coupled with a shape that resembles a calf or hips of a woman is very possible that faint sound mellow and alluring. Marwasis also very important because the structure is simple but has an impressive rhythmic instrument so as to tradition percussion, biased tone no less competitive with other percussion instruments. Psaltery playing with serene, Marwas formations with squeaked in variety of senting and dogoh 
(forte) institutionalized accompany dance beautifully captivating the hearts of every person who witnessed it. The power of both this instrument adds to excitement for dancer, giving eminent, and relieve taste those who see that so imperceptibly pass demonstrate harmony of the dancers in the dance. Furthermore punch one, two and three as well senting and dogoh produced by Marwas give accentuate on pace and range of motion in dance knits so steps broken and halting movement as if creation. The combination is centrum Zapin in dynamics and tempo rather fast as sukatan (Nor, 2001).

In Zapin, Gambus string must first stringed continue the singer sing song. Then, Zapin banker step and move in accordance with the rules of diversity that are served. Gambus sound is as driving, setting, controller and resolver Zapin dance. The song is sung to initiate Zapin is a song called Bismillah. Bismillah is an unfamiliar phrase to a Muslim because of Bismillah pronounced when it will start each job. The Prophet said, "Every matter that does not begin with Bismillah (in another narration: the remembrance of Allah), then the practice is disconnected (less) his blessings."

Muhd.Abduh said in his commentary that "Al-Qur'an is the priests and role of us, because Al-qur'an begins with Bismillah. That's a guide for us that all our actions begin with reading Bismillah. "Thus Zapin teach people always mention Allah when doing any work. This is one of education element that is worth morality contained in Zapin where Bismilah contains virtues, that is protected by God from against Jin and Satan as saying of the Prophet: " The barrier between the eyes of Jinn and the nakedness of Children of Adam, when one of them took off his clothes, is to read Bismillah."

Furthermore, if we read Bismillah, God will protect from people who intent evil. An event when Khalid bin Walid crushed by indecision, they said to him, "Beware of poison, do not let strangers give drink to you," he said, "give me," and he took his hand and read: "Bismillah, "and then he drank. So did not give the slightest danger to him. Hadits clarify how important to say Bismillah when it will begin a daily work are positive. In this case, zapin significantly provide a good example to the performers and the audience to act and behave religiously.

Furthermore, from song and voice and string psaltery performed simultaneously implies togetherness. That is unity psaltery sound sung with a stringed instrument sound wave string performed simultaneously or in tandem. This means that any sound echoed string psaltery. This implies that unity is necessary because life cannot be done alone, life should not be alone as social beings, and humans would have an interest with other humans. Therefore, human life should not be split apart as the word of Allah in Surah Ali Imran verse 103:

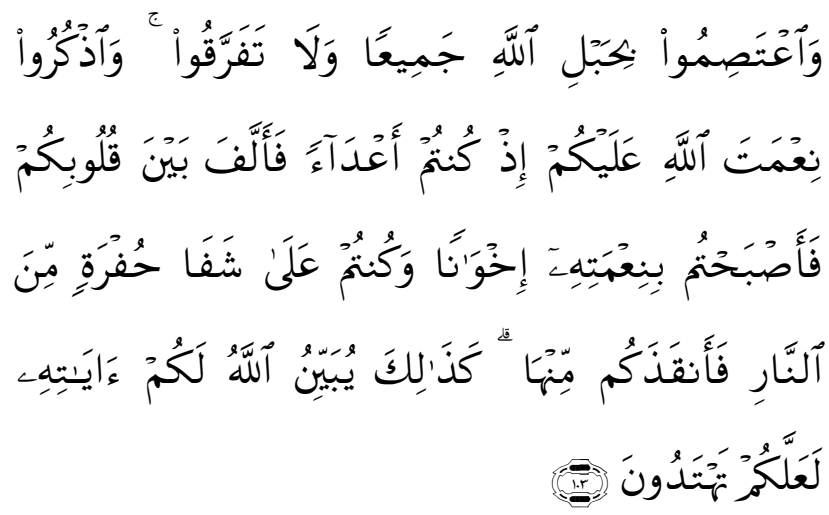

And hold fast, all together, by the rope of Allah, and be not divided among them. And remember Allah's favour upon you. Remember when there was enmity among you, He joined your hearts together then, by His grace, you became brothers together and you were upon the brink of a pit of Fire, then He rescued you from it; Thus Allah explains to you His signs; that haply you may act guidance. 
Similarly, in verse 105

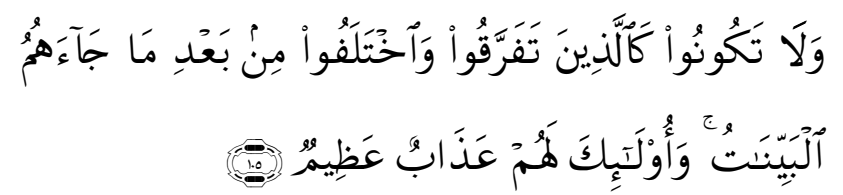

And be not like those who were divided (in sections) and disagreed among themselves, after this that bright signs had come to them and for them there is mighty torment.

In verse above, Allah Swt warned again Muslims are not like previous followers always differed, broken to pieces and hostile and indulgence. The divisions also have occurred in the Book, God warned not to Muslims as well as previous followers hostile and fragmented, deviating from teachings of Al-Qur'an and creating new things (bid 'ah). Furthermore, Rasulullah also asked Muslims to unite and do not divorces disarray, as where his word that translates:

"Allah bless you in three ways, bless you worship Him and not consider as an allyHim with anything; you stickle to the rope (religion) of Allah and do not divorce disarray; and sincere your love to those who were given authority by God, or yours. He hates three things, namely the story of mouth; too much to ask for; and a waste of money". (HR. Muslim)

Togetherness embodied in Zapin music is the implementation of Core Competence K.13 where unity and integrity are a human attitude has a moral and ethical life. Morals and ethics are a reflection of positive attitude for people who have mental religious. Thus the existence of Zapin as a traditional art gives power to K.13.

\section{Core Competence in Zapin Dance}

Value core competencies contained in Zapin dance seen in variety dance such as first variety of Zapin dance is variance 'alifsembah'. This variety is as a beginner or starting of Zapin dance which implies respect to other when meet and visit. Comity is the attitude of principle human to anyone and closer with Islam teachings where Islam strongly affirm to the people in honor of guests as the word of the Prophet Muhammad SAW : For those who believes in Allah and the Last Day, then glorify his guests.

In the Zapin dance, honor the guest is the most important made. Therefore, it conducted in early Zapin dance as an opening. Honoring the guest is a work very pleasing to Allah SWT. Moreover, the guests respect became one of cause's declines Al-Qur'an verses. For example, event emigration of Muslims with the Prophet Muhammad SAW went to Medina where Anshor families with all the pleasure welcome their guests that is Muhajirin family by providing food and shelter. Because of this case then there came word of Allah in Surah Al-Hasr verse 9:

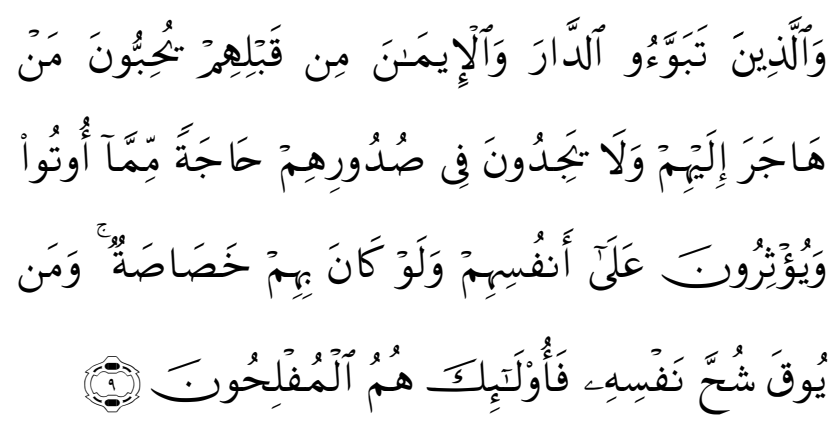

And [also for] those who were settled in al-Madinah and [adopted] the faith before them. They love those who emigrated to them and find not any want in their breasts of what the emigrants were given but give [them] preference over themselves, even though they are in privation. And whoever is protected from the stinginess of his soul it is those who will be the successful.

The verse above illustrates that glorify or entertaining guests is not only the morality of the Prophet Muhammad and his companions but also the morality of the previous prophets, as God profiled about Prophet Ibrahim in surah Adzaariyaat verses 24-27: 


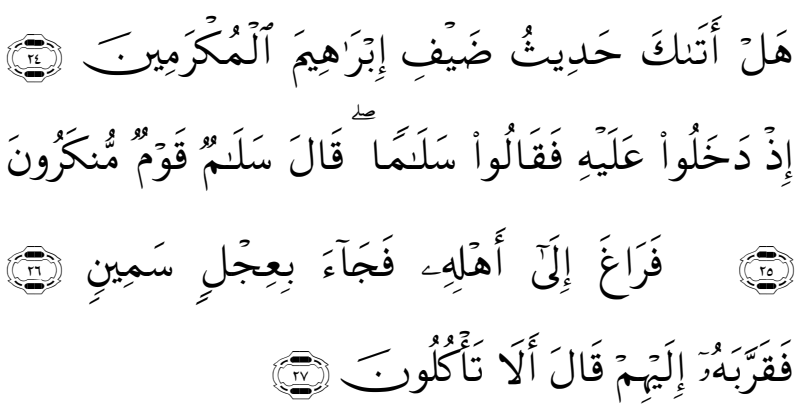

Has there reached you the story of the honoured guests of Abraham? (24) When they entered upon him and said, "[We greet you with] peace." He answered, "[And upon you] peace, [you are] a people unknown. (25) Then he went to his family and came with a fat [roasted] calf (26) and placed it near them; he said, "Will you not eat?" (27)

Therefore, basically a variety of 'alifsembah' implies greetings, salutation, scolds and accosts, bring friendship sense and binding relationship. Variety of 'alifsembah' is also an emblem or handshake symbol through the motions in a variety Zapin strands. Variety of 'alifsembah' also means sincerity, mental clarity, and personal linguistic and behavior in expression through movement and steps in an appreciation Zapin dance. Variety of 'alifsembah' has akhlakul karimah value for the actors and audience. It's meant the existence of diversity in Zapin dance strongly support the existence of K.13 especially in applying core competencies.

The second variety is variety 'anak ayam patah'. This variety is reminiscent us to animals are also creatures of Allah. Movement of a chick who broke his leg became a variety in Zapin dance. This is beneficial as learning in one's life and spirit of struggle in achieving ideals. Unyielding attitude thrown away, desperation fought and destroyed, perseverance and sincerity strengthened themselves in order to face a variety of obstacles. The main example is the Prophet Muhammad who never gave up on teaching preaching to his people. Desperate is vices that do not should be maintained because can make men lose the passion for life, lose the passion for work and activities of everyday life, there is a sense of sadness, guilt, slower thinking, immune deficiencies, easily hurt because there is only a view empty as if crushed by a very heavy burden is on his shoulder. Allah dislike men who easily despair as said in Al-Qur'an Surah Yusuf verse 87:

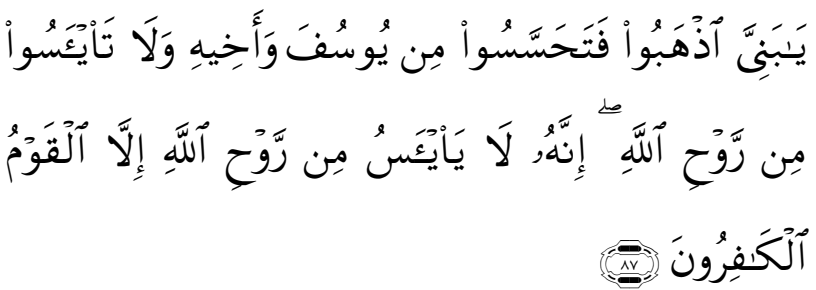

O my sons go and find out about Joseph and his brother and despair not of relief from Allah. Indeed, no one despairs of relief from Allah except the disbelieving people."

In the verse above, Allah SWT tells about the advice of Prophet Yusuf AS that other children who seek news of Joseph and his brother Benyamin. And the prophet Jacob advised his sons are not to despair of the mercy of Allah SWT in finding them, because those who despair of the mercy of God that only unbelievers.

The parable 'anak ayam patah' as a variety of Zapin dance signaled that physical shortage is not a reason in reaching an expectation. The value containing in a variety of 'anak ayam patah' presents an overview and force someone in life. No words could not, nothing is unattainable as long as ikhtiyar do. Life is a struggle and struggle is the key to success. Sail never receded backward. Once paddle embraced two of three islands too. Working hard with the intention earnest, God willing wishes can come true. People who are accustomed to living their hard work is always working to solve the problem unresolved.

On the other hand, the learning value contained in a variety of 'anak ayam patah' of Zapin dance in question the nature of honest and brave prioritizes as attitude is. In other 
words, it distanced snobbery and low selfesteem, discarding vanity, both tangible and intangible. In addition, the variety of 'anak ayam patah' contained in Zapin dance symbolizes the resilient attitude and humble nature. As proverb say climb up to the top, to sail up to the limit, climb to the top and dropped to basic.

Furthermore, a third variety of Zapin dance that express akhlakul karimah is movement 'minta tahto' as a sign of the end of Zapin. Movement 'minta tahto' is as a salute to end Zapin. This means that excuses resigned from the room or person. This Zapin Variety contains ethics order when face with people. In Malay teaching point say 'datang tampak muka, pulang tampak punggung'. Malay teaching point is very consistent with the teachings of Islam. Likewise, the concept K.13 implemented on core competencies.

Further, core competencies that should not be overlooked is the traditional Zapin dancers consisted of men only, while women are not allowed to dance let alone with a man. This is in accordance with the teachings of Islam in which women are forbidden to demonstrate of her body movement in front of opposite sex. This case is implemented in Zapin dance so it supports Core Competence containing live attitude and practice religious affiliations. Consider the following picture.

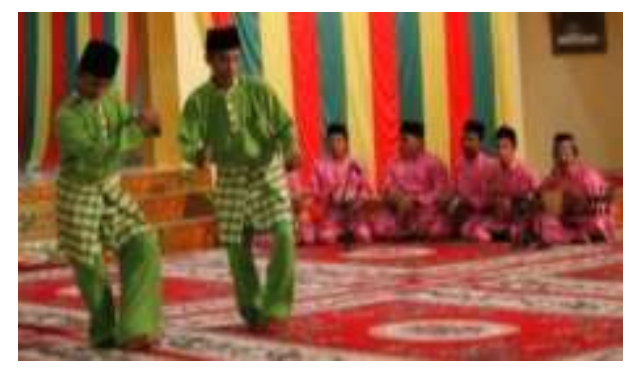

Figure 3. Traditional Zapin

Nowadays in its development, there are also women who perform zapin but still only paired with women as well. This means that there is Islamic ethics value contained in Zapin. In another aspect, Zapin dance traditionally is done on a rug that is at the bottom on pedestal with a rattan mat. If a successful dancer dancing on a rug without a contract, then the dancer is said to be successful. Perform zapin on a bed rug underneath a rattan mat meant that the movement should be done carefully and responsibly to avoid wrong and mistakes. It can be tried and proved that if you do Zapin motion at will on a rug beneath which certainly rattans mat so rug is matted.

\section{Support of Traditional Zapin For Curriculum 2013}

Malay identical with Islam is a common statement heard by the public since Islam came and development in archipelago. Likewise, Zapin is one of the arts that were carried on by Islamization process in archipelago. Thus, Zapin is as a traditional art developed in archipelago which implemented from statement because contain Malay teaching point identical with Islam. Zapin with all the elements mean having an educational content, especially the content of moral and attitude education. It is very appropriate that National Education System stated in UU No.20/2003 on $3^{\text {rd }}$ article which says that the function of national education is to develop skills and character and civilization of the nation's dignity in context of intellectual life. Whereas, National education goals is to develop potential students to be faithful and devoted to God Almighty, noble, healthy, knowledgeable, skilled, creative, independent, and become citizens of a democratic and accountable.

If it is linked with K.13 which was announced by the government now, Zapin art can be regarded as one strengthening aspect for implementation K.13 because it is designed to prepare Indonesian people have the ability to live as individuals and citizens who believe, productive, creative, innovative, and affective and able to contribute to the society, nation, state and world civilization.

In accordance with ideology and Indonesia culture, the implementation of 
national education system in Indonesia at every qualification level includes processes that foster affection as follows (1) devoted to God Almighty; (2) have a moral, ethical and personality in task completing; (3) role as citizens who take pride and love of homeland and to support world peace; (4) able to work together and have a social sensitivity and concern towards society and environment; (5) appreciate cultural diversity, views, beliefs, and religion and opinion/original findings of others; (6) upholding the rule of law and have spirit to put nation interests and wider community.

Everything become the purpose of implementing K.13 can be said that traditional arts, especially Zapin oriented on concepts of K.13 are implemented core competencies that include first: faith and piety to God Almighty; second: character; Third: scientific; Fourth: skills. According to Mulyasa (2013) that K.13 can produce Indonesia man productive, creative, innovative, affective through strengthening of attitudes, skills and integrated knowledge. Therefore, it can be said that Zapin as a traditional art contributed to the strengthness of curriculum 2013.

\section{CONCLUSION AND RECOMMENDATION}

Based on the explanation above, at the end of this paper can be concluded that (1) Zapin as Malay traditional arts community or archipelago and Indonesia, and it can be called existence of zapin is to support the implementation of curriculum 2013 program; (2) the existence Zapin as strengthening K.13 reflected on fixtures and fittings of the music, song and Zapin dancers; (3) the music procession, song and Zapin dance is the implementation of Core Competence 1 and Core Competencies 2, as contained in curriculum 2013; (4) Malay traditional Zapin with all elements give positive contribution to the implementation of curriculum 2013 in Indonesia.
It is recommended in selecting the teaching materials when implementing curriculum 2013, it should be also considered about the value of traditional arts. As in Zapin in Riau context, there would be the value of the attitude of togetherness that is contained Zapin which becomes an implementation of the core competencies in curriculum 2013. It indicated that the unity is a human behavior that has moral and ethical of life. Morals and ethics are a reflection of attitude for humans who have religious mental. Thus, the existence of Zapin as traditional art gives strengthness to the curriculum 2013.

\section{REFERENCES}

Abdullah, N. F. L., \& Pakri, M. R. (2013). Retracing tradition for a sustainable future: the Malaysian experience. Penerbit USM.

Alfirafindra, R. (2012). Peran majlis pusat pertubuhan-pertubuhan budaya melayu singapura dalam festival tari serumpun. Jurnal Seni Tari, 78.

Anderson, E. (2013). Middle east: Geography and geopolitics. Routledge.

Arzull, M. B. (2002). Gambus Melayu Riau Di Kota Pekanbaru (dari atas perahu ke pentas pertunjukan). Sosiohumanika, 15(2002).

Astuti, S. V. (2016). Tari Zapin Bengkalis: bentuk, karakteristik, dan perkembangan. Institut Seni Indonesia Surakarta.

Berg, B. (2007). Presence and Power of the Arab idiom in Indonesian Islamic Musical arts. In Conference on Music in the world of Islam, Assilah (pp. 8-13).

Bernard, H. R. (2011). Research methods in anthropology: Qualitative and quantitative approaches. Rowman Altamira. 
Bryman, A. (2006). Integrating quantitative and qualitative research: How is it done? Qualitative Research, 6(1), 97-113.

Burridge, S. (n.d.). Keynote presentation: Nanyang Academy of Fine Arts Education conference 2013.

Chan, C., \& Ching, S. (2012). P. Ramlee's music: An expression of local identity in malaya during the mid-twentieth century. Malaysian Music Journal, 1(1), $16-32$.

Chong, S., Rohwer, D., Emmanuel, D., Kruse, N., \& Smilde, R. (2013). Community music through authentic engagement: Bridging community, school, university, and arts groups. Community Music Today, 151-168.

Creswell, J. W. (2013). Research design: Qualitative, quantitative, and mixed methods approaches. Sage publications.

Creswell, J. W., \& Clark, V. L. P. (2007). Designing and conducting mixed methods research.

Elo, S., \& Kyngäs, H. (2008). The qualitative content analysis process. Journal of Advanced Nursing, 62(1), 107-115.

Farrer, D. S. (2012). The Performance of enchantment and the enchantment of performance in Malay Singapore. Moussons. Recherche En Sciences Humaines Sur l'Asie Du Sud-Est, (20), 11-32.

Firzal, Y. (2015). Reconstructing socio-cultural identity: Malay culture and architecture in Pekanbaru, Indonesia.

Freud, S. (2015). Civilization and its discontents. Broadview Press.

Glatzer, B. (2002). The Pashtun tribal system. Concept of Tribal Society, 5, 265-282.
Hilarian, L. F. (2005). The gambus (lutes) of the Malay World: its origins and significance in Zapin Music. Nanyang Technical University of Singapore, Singapore, 8-13.

Houston, S., Stuart, D., \& Taube, K. (2013). The memory of bones: body, being, and experience among the Classic Maya. University of Texas Press.

Hsieh, H.-F., \& Shannon, S. E. (2005). Three approaches to qualitative content analysis. Qualitative Health Research, 15(9), 1277-1288.

Junita, A. (2015). Tafsir gerak tari zapin Salabatul Laylan Kecamatan Tanjung Tiram Kabupaten Batu Bara. UNIMED.

Kartomi, M. (2012). Musical journeys in Sumatra. University of Illinois Press.

Meddegoda, C. P. (2013). Adaptation of the harmonium in Malaysia: Indian or British Heritage? Asian Studies, 70(3), 679.

Mulyasa, E. (2013). Pengembangan dan implementasi kurikulum 2013. PT Remaja Rosdakarya.

Neuman, L. W. (2002). Social research methods: Qualitative and quantitative approaches.

Nor, M. A. M. (2000a). Hala Tuju Tarian Melayu di Alaf Ketiga. Di Dalam Tirai Panggung, Jil, 3, 58-69.

Nor, M. A. M. (2000b). Zapin Melayu di Nusantara. Yayasan Warisan Johor.

Nor, M. A. M. (2001). Blurring images, glowing likenesses: Old and new styles in traditional dances of Malaysia. Yearbook for Traditional Music, 65-71.

Nurdin, N. (2016). Perkembangan fungsi dan bentuk tari zapin Arab di kota Palembang (1991-2014). Gelar, 12(2). 
Othman, M. R. (2005). Islam dan masyarakat Melayu: peranan dan pengaruh Timur Tengah. Penerbit Universiti Malaya.

Peckham, R. S. (2001). National histories, natural states: Nationalism and the politics of place in Greece. IB Tauris.

Ritawati, T. (2017). The original of Malay songs (oms) as the symbolism of Malay cultural heritage. International Journal Of Social Sciences, 49(1).

Ross, L. N. (2011). Rong ngeng The transformation of Malayan social dance music in Thailand since the 1930s. City University of New York.

Shuaib, A., Olalere, F. E., \& others. (2013). The Kelantan traditional arts as indicators for sustainability: an introduction to its Genius Loci.
Sulistiyono, S. T., \& Rochwulaningsih, Y. (2013). Contest for hegemony: The dynamics of inland and maritime cultures relations in the history of Java island, Indonesia. Journal of Marine and Island Cultures, 2(2), 115-127.

Tamrin, H., \& Nur, A. (2007). Pemetaan Kebudayaan Melayu Riau. Laporan Hasil Penelitian Universiti Islam Negeri Sultan Syarif Kasim Riau Pekanbaru.

Thomas, D. R. (2006). A general inductive approach for analyzing qualitative evaluation data. American Journal of Evaluation, 27(2), 237-246.

Wolf, E. R. (2010). Europe and the people without history. Univ of California Press. 